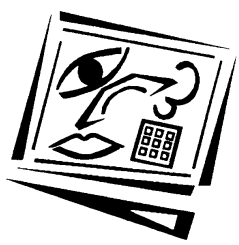

\title{
Learner centredness in high school distance learning: Teachers' perspectives and research validated principles
}

\author{
Elizabeth Murphy and Maria A. Rodriguez-Manzanares \\ Memorial University of Newfoundland and Labrador
}

\begin{abstract}
This paper reports on a study that examined teachers' perspectives on learner centredness in a distance learning context. Data collection relied on semi-structured interviews conducted with 42 Canadian high school teachers. Teachers' perspectives were analysed then categorised according to the four dimensions of a research validated framework of learner centred principles. The perspectives grouped into the cognitive and metacognitive dimension emphasised the goal oriented, student directed, personalised, and independent nature of distance learning. Those grouped into the dimension of motivational and affective factors emphasised course design driven, not by content, but by student interest, relevance, choice, and input. Perspectives in the dimension of developmental and social factors highlighted the role of discussion forums and chat for communication between students. In the dimension of individual differences, perspectives highlighted the asynchronous nature of distance learning that supports a flexible pace, respects individual needs, caters to different learning styles, allows diversity in assessment, one-on-one attention, support, and personalised attention.
\end{abstract}

\section{Introduction}

Bonk and Cunningham (1998) identified learner centredness as a theoretical perspective relevant to educational environments where electronic tools are used. They highlighted the value of the American Psychological Association's (APA) framework of Learner Centred Principles (LCPs) (APA, 1993; APA, 1997). A learner centred perspective relying on the LCPs can connect research evidence with practice (Lambert \& McCombs, 1998) and help conceptualise a role for technology in education that derives from theoretical principles and validated teacher practices (McCombs, 2000). The LCPs present an approach to learner centred instructional design that focuses, not on tool use, but on learning (Carr-Chelman \& Savoy, 2004). The principles can serve as a foundation for "systemic, educational decision making" (Lambert \& McCombs, 1998, p. 8) and for educational reform as well as the redesign of schools (APA, 1997).

Carr-Chelman and Savoy (2004) identified a strand of empirical studies related to the LCPs which relies on use of the Assessment of Learner Centred Principles (ALCP) surveys. The surveys are validated instruments (see McCombs, 2004; McCombs \& Lauer, 1997) and include both student and teacher versions. They were developed as learning tools for teachers (Crick \& McCombs, 2006) and have been used for assessment of teacher practices. Studies have been conducted in which the surveys are administered either to teachers, students, or both (e.g., Daniels, Kalkman \& McCombs, 2001; McCombs, 2001b; McCombs \& Quiat, 2000a, 2000b; Weinberger \& McCombs, 2001). McCombs 
and Quiat's study investigated both teachers' and students' perspectives of learner centredness in the context of a school reform program. The authors relied on the ALCP surveys to identify teachers as "high implementers" and "low implementers" of the program. Findings revealed that teachers who were high implementers were more likely to perceive themselves as engaging in higher levels of learner centredness than were low implementers. In addition, student data showed that high implementers were perceived by students to be more learner centred than were low implementers.

Weinberger and McCombs (2001) conducted another study relying on the ALCP surveys. They found correlations between teachers' beliefs and students' perceptions and motivation, but higher correlations were found between students' own perceptions of teachers' learner centredness and student motivation, achievement, and behaviour. In relation to the perspectives of both learners and teachers and how these relate to learner motivation and achievement, findings also suggested that the relationships between teachers' perceptions of their practice and student motivation and outcomes become stronger as teachers move towards more learner centredness.

Carr-Chelman and Savoy (2004) identified other types of empirical studies of learner centredness which they divided into two categories: those that focus on teachers' philosophies, understandings, perceptions, attitudes and abilities, versus those that focus on learning outcomes (e.g., Brush \& Saye, 2000; Salisbury-Glennon, Gorrell, Sanders, Boyd \& Kamen, 1999). With regards to the former, researchers have used interviews to examine teachers' understandings of learner centredness in a context of curriculum innovation (e.g., Paris \& Combs, 2000) and others have used large scale surveys of teachers' philosophies and attitudes about learner centred teaching (e.g., Williams, 1996). Williams' study was conducted with more than 400 teachers from 10 urban high schools. One of the study's findings was an apparent incongruity between some teachers' expression of "traditional philosophical attitudes" and of learner centred attitudes at the same time. According to Williams, an explanation of this finding might be that "the demands of the teaching environment were such that the teachers' progressive beliefs were swamped in favour of more traditional beliefs" (p.1).

Paris and Combs (2000) interviewed experienced elementary, high school, and postsecondary teachers participating in an educational reform program focused on learner centred teaching. The purpose of the study was to investigate the meaning that the teachers ascribed to the concept of "learner centred" instruction. The study resulted in the articulation of a definition of learner-centredness which included five components: "the teacher's focus is on the learners; the teacher guides and facilitates learning; the teacher promotes active learner engagement; the teacher promotes learning through interactive decision making; and the teacher is a reflective, ongoing learner" (p. 1). Paris and Combs compared concepts in the literature on learner centredness with those emerging from teachers' perspectives in their study and found that there was more emphasis in teachers' perspectives than in the literature on "students' participation in planning and assessing learning activities" (p. 16).

An emerging strand of research investigates the LCPs in educational technology contexts. Somerindyke's (2001) ethnographic case study of integration of technology in a fourth-grade, face to face classroom found that teachers engaged in more learner centred practices when computers were in high use. Somerindyke also found that there were some constraints with respect to use of computers in terms of student engagement in collaborative activities. Vakili's (2003) study of six online, post- 
secondary courses relied on the student and instructor ALCP surveys to investigate motivational variables and learner centred practices in face to face versus online contexts. With respect to perceptions of learner centredness, except for one course and one construct for another course, teachers perceived the courses to be more learner centred than did the students. When discussing teacher practices, Vakili observed that "the online students believe that the instructor encourages personal challenge and responsibility yet is less likely to provide for individual and social learning needs" (p. 115).

Ware (2006) conducted a qualitative study in a post-secondary context which focused on instructors' and learners' perceptions of web based learning and learner centred pedagogy. Data collection relied on the ALCP surveys, observations, as well as interviews with six instructors. The study included an examination of each of the instructors' beliefs about learner centred instruction in their face to face versus their online courses. Ware found that instructors perceived by learners as more learner centred in face to face classes were perceived to be so in their online courses as well. Instructors perceived as less learner centred than other instructors were perceived to be so both face to face and online.

The review of the literature conducted for the study reported on in this paper did not uncover any studies using the LCPs conducted with a focus on distance learning exclusively, as opposed to distance versus face to face comparisons. However, McCombs and Vakili (2005) have argued in favour of use of the LCPs framework in the design of new forms of learning emerging in online, distance learning contexts, noting that these forms rely less on content and more on context, meaning, communication, and community. The study reported on in this paper examines learner-centredness, not in face to face contexts, but in distance teaching and learning. It examines learner centredness, not as a theoretical construct, but as a phenomenon about which distance teachers have experience, knowledge, and understandings. The study relied, not on surveys, but on semi-structured interviews to identify 42 Canadian high school teachers' personal perspectives on learner centredness in a context of distance teaching and learning. Perspectives were grouped based on key terms and concepts, then associated with one of the four LCPs dimensions. The paper begins with an overview of the LCPs.

\section{The Learner Centred Principles}

The LCPs were formulated as a result of an APA Task Force on Psychology in Education (APA, 1993) aimed at creating a framework that might guide school redesign and reform. The Task Force represented a combined effort of the APA and the Mid-continent Regional Educational Laboratory. Both groups were preoccupied with the lack of impact of research and theory on school reform (Bonk \& Cunningham, 1998). The original Task Force document listed 12 principles (APA, 1993). When the document underwent revision in 1997, two more principles were added (APA, 1997).

The 14 principles are organised into four dimensions of factors as follows:

A. Cognitive and metacognitive factors (six principles);

B. Motivational and affective factors (three principles);

C. Developmental and social factors (two principles);

D. Individual differences factors (three principles) (APA, 1997). 
A description of the 14 principles is available in McCombs and Vakili (1995) and Bonk and Cunningham (1998). Murphy and Rodriguez-Manzanares (2008b) provide a synthesised description of the four dimensions of the LCPs which we reproduce here:

A. Cognitive and metacognitive factors:

The learner constructs meaning and links new information with existing knowledge, applies a repertoire of learning strategies including higher-order strategies, pursues personally relevant goals, and is influenced by the context of learning.

B. Motivational and affective factors:

Motivation is influenced by emotional states and learners' beliefs about themselves as learners and is facilitated by meaningful and appropriate in difficulty, real-world tasks with choice and control. Learner effort and commitment is an indicator of motivation.

C. Developmental and social factors:

Learning is most effective when developmental levels, across intellectual, emotional, and physical domains, and social interactions are taken into account creating a positive climate for learning.

D. Individual differences factors:

Learning is most effective when learners examine their learning preferences, appraise their strengths and weaknesses, receive assessment at all stages of the learning process, and when they perceive that their linguistic, cultural, and social backgrounds are taken into account. (p. 385)

According to McCombs (2000), the principles apply to all learners and, although they were not designed in relation to educational contexts where learning is supported by technology, they can be applied to these contexts (e.g., Bonk, Appelman \& Hay, 1996; Bonk \& Reynolds, 1997; McCombs, 2000; McCombs \& Vakili, 2005; Wagner \& McCombs, 1995). McCombs (1997, 1999, 2001a, 2003) and others (e.g., McCombs \& Miller, 2007; McCombs \& Pierce, 1999; McCombs \& Whisler, 1997) have relied extensively on the principles (see Alexander \& Murphy, 1998). We selected the APA's LCPs because they were research validated and provide a framework of clearly identified principles. Readers interested in other approaches to studying learner centredness that do not rely on the LCPs may wish to consult Hannafin and Land (1997), Reilly (2005), Seufert, Lechner and Stanoevska (2002), or Weimer (2002).

\section{Methods}

Forty-two, high school, distance teachers were recruited to participate in the study from western (British Columbia, Alberta, Saskatchewan, and Manitoba), central (Ontario and Quebec), and eastern (New Brunswick and Nova Scotia) areas of Canada. We focused only on distance learning in an Anglophone context. It was beyond the scope of the study to include education delivered in French to French first-language speakers. Our study was a follow up to a case study conducted in the province of Newfoundland and Labrador (See Murphy \& Rodriguez-Manzanares, 2008a). Findings from that study led us to focus on five issues as follows: learner centredness; motivation; rapport and community; synchronous versus asynchronous distance learning; and improving distance learning. This paper reports on the issue of learner centredness.

We selected all teachers who agreed to participate in the study and who provided consent. In order to be eligible to participate, the teacher had to be teaching one or more high school courses delivered entirely at a distance. Thirty-eight teachers had 
taught previously in an online setting of distance learning, with years of experience ranging from one to 10 . Of the four teachers who had not taught online, one had used video conferencing and the other three had taught non-web based, correspondence courses. Eighteen of the participants taught full time and 100\% online. The majority worked from within an office in a brick and mortar school, six worked from home, and 10 from an office outside the home but not in a school.

We gathered teachers' perspectives using semi-structured (Patton, 2002) interviews conducted by telephone. Interviews lasted approximately one and a half hours with each of the 42 participants for a total of about 60 hours. One part of the interview focused on learner centredness with the following questions: What does it mean for you to be learner centred in a distance course?; What might learner centredness look like in a distance education context?; How do you know if your classroom is learner centred?

Interviews were recorded digitally, archived, and then transcribed in their entirety. One coder broke down the text of each transcript into units of analysis, a process which involved marking off "units that cohere... because they deal with the same topic" (Miles \& Huberman, 1994, p. 57). We chose the unit of meaning as our unit of analysis, "a statement or a continuous set of statements, which convey one identifiable idea" (Aviv, 2001, p. 59). Next, the coder analysed all statements pertaining to learner centredness and used recurring terms and concepts to group together similar statements. For example, all statements from the transcripts with the words one-on-one were placed together under the label of those words. A second individual then reviewed the grouping of all statements. Both individuals worked toward consensus in the groupings. Like statements were deleted and the data reduced. The coder then associated statements with one of the four LCP dimensions of factors (A. Cognitive and metacognitive factors; B. Motivational and affective factors; C. Developmental and social factors; and D. Individual differences factors). To facilitate this process, the coder relied on a version of the summary of the dimensions of LCPs referred to earlier (see Murphy \& Rodriguez, 2008b) that included key words for each dimension. Another individual then verified the associations. Where there was lack of agreement on the association of a statement with a particular dimension, the coder and the second individual worked towards consensus.

\section{Teachers' perspectives on learner centredness in distance learning}

The perspectives were associated with one of the four dimensions of the LCPs and reported, as much as possible, using the teachers' actual words.

\section{A. Cognitive and metacognitive factors}

Decisions about how to learn might be up to the student, such as "how much they read or don't read" or "how they're going to take notes." The focus might be on students doing their own research and taking initiatives. The teacher may provide attention to students on an "on-demand basis," whereby "the more they ask, the more they get." Students are in "the driver's seat" when they decide they want to ask questions. Courses might be designed using tutorials and supplementary materials "to have students gain the skills on their own without necessarily having to wait to ask a teacher." Distance learning delivered online fits students with "specific goals" who can reach those goals on their own. Teachers have to "help the students find the answer 
themselves" by giving them the tools they need and "providing them with an opportunity to use the information."

Teachers can involve students by "moving away from a lot of question-and-answer type of activities" in order to "allow for student creativity, to let them show what they know and what they can analyse and synthesise." They might ask for students' personal response to or opinions on different topic or experiences that relate to the course. They can get feedback from students to help them see personal relevance. Students can be "learning how to learn" and not just be "spoon fed" by the teacher.

In contexts where students are registered in schools, a teacher or local facilitator might be assigned to be responsible for the students' distance learning support. Students might come to a classroom that has computers and work on their courses with the help of a facilitator. Their role is to "monitor students, for problems or questions." If teachers are noticing any problems, they can contact the local facilitator.

\section{B. Motivational and affective factors}

Teachers can allow students "to make choices more localised or community driven." They can allow students "to go and find something that would be of interest to them." A course can be designed to have three or four different assignments that would fulfil the same outcome to provide students with variety. Students might also choose how they want to present their assignment, for example through a brochure or a slideshow.

Teachers might ask students for feedback, input, suggestions, and opinions and implement that in course redesign because "if you want to know about something, the best way is just to ask students." Teachers can ask them, "If you were to re-do it, how would you do it?" and ask themselves, "If I were trying to take this course as a kid, what would I want and what would I need?" Students' comments can help make changes to improve their success.

Courses should be designed to be as interactive as possible in order to capture and maintain interest. This interactivity might be achieved through Flash, videos, animations, and tutorials. The objective is "to present the students with a course that... they can relate to," and to make the design and its materials "concrete, practical, dealing with real issues." Teachers should keep in mind that the course is "for the students and for them to learn and advance... rather than being content-centred....".

\section{Developmental and social factors}

Students can work with partners to answer questions and to post or respond to the comments of others in a discussion. They might lead the discussion with other students and the teacher just "sits back and acts as a guide." Students might have to take responsibility with the other members of the class; for example, they know that, if they come to a chat with no questions, the teacher might say "anybody provide some help here?" Teachers might also "keep things purposefully vague" in order to see what the students can come up with in a collaborative manner.

Teachers have to be more open to other factors that are going on in students' lives and must consider family needs or personal illness. They need to "engage the student as an individual as much as possible and be aware of them individually." Teachers must put themselves in the position of students, "seeing what their viewpoint is from where 
they sit in whatever classroom and community they're in, how they're going to navigate their way through this course and be successful in the end." The focus is on whatever it takes to have them do well.

\section{Individual differences factors}

Being teacher centred would be more "here's the curriculum, here's what you need to do, and we're going to get through it by hell or high water." One way of knowing if a course is learner centred is if students have travelled through the course in a unique way, different from another student, as opposed to everyone doing exactly the same thing, in exactly the same way. Teachers also have to see things "through their eyes." Teachers can modify the course to accommodate disabilities or lack of knowledge so students can be successful because "every kid has a different need in the online system."

Teachers have to make themselves available to students, offer one on one assistance, and give students "as much time as they want or need." The time spent will "depend on that student's needs." If a student says, "this isn't working for me," the teacher may find out why, learn from the student and, if there are issues, then work out alternatives and a different approach that will allow the student to be successful.

Courses and assignments have to be user friendly with variety and options to allow the students to "excel at their learning style of choice." If a student is more visual, he or she might be allowed to do an assignment using images. It is important that teachers be willing to allow students to learn in any way they choose. For example, if a student has trouble with an assignment, a teacher might ask, "What would work for you?; How do you want to do it?" Teachers have to be flexible. Someone from the school may contact teachers to make sure that they have all the information about students' learning styles.

Teachers might have less formal exam sessions to reduce the anxiety and the pressure on students who are high-functioning but very anxious or who are "psychologically unable to participate in the regular system." If students come to a context of online learning not being able to "survive in the regular classroom," or unable to "cope in class with thirty kids" or with "changing teachers all the time," they might meet with their teacher face to face to work on self esteem or on individual issues. Support can be provided online or in person through school or district counsellors who do learning programs for each student.

Students need lots of choice and lots of freedom to travel through the course in their individual way. They might do a slideshow presentation, a written response, or an oral presentation to demonstrate their learning. They might also prefer to work individually or in groups and select from different projects that best suit their needs. They might choose to "do a photo story instead of their research paper in more of written context." It is possible for teachers to "individualise the experience" according to what students are choosing to read and in what sorts of ways they are presenting their knowledge.

Face to face visits might involve one or two outings per year to attend sports games, graduation ceremonies, or parent-teacher interviews. In organisations with few students enrolled per course, teachers might "go the extra mile... and visit them" or 
even "be on the road all the time" to see distance students in their schools and "offer a more personalised service." In other contexts, teachers might go to a school to help resolve an issue or if "students are not producing any work" or to have a face to face chat with them. Some students might prefer to have their own tutorial face to face.

In some contexts, students may decide when they do the course or cover the material. They can go through the course out of sequence or take a week off or do a lot of work in a very short period of time. Teachers may adjust "to the pace of the student." Teachers might need to be flexible because a lot of students don't necessarily work on a timeline, a normal day. In asynchronous environments in particular, giving students that time to do what they need is "the big thing."

In a learning environment with no synchronous interactions, "interactions are one on one, because they're asynchronous." The teacher is working one on one with students, "in the sense that when they're emailing ... [the teacher is] directly dealing with their issues,... not dealing with all the other issues." Learning is one on one when a student submits a lesson and they get a one on one response back from the teacher, in the form of comments or an email. Written assignments such as journals can involve quite a bit of one on one time. Besides using email, teachers may offer private chats online if there is something students don't understand, because some students "really benefit [...] from one on one attention." Teachers might afterwards even ask if they can post the chat so the others in the class can see it.

\section{Discussion}

The perspectives grouped into the cognitive and metacognitive dimension emphasised the goal oriented, student directed, personalised, and independent nature of distance learning with the teacher as an on-demand helper who provides students with the tools to work on their own. Those grouped into the dimension of motivational and affective factors emphasised course design driven, not by content, but by student interest, relevance, choice, and input. Perspectives in the dimension of developmental and social factors highlighted the role of discussion forums and chat for distance communication between students. In the dimension of individual differences, perspectives highlighted the asynchronous nature of distance learning that supports a flexible pace, respects individual needs, caters to different learning styles, allows diversity in assessment, one-on-one attention, support, and personalised attention.

The dimension of developmental and social factors of the LCPs focuses on awareness and understanding of developmental differences as well as social influences on learning. However, teachers' perspectives did not identify a prominent role for social interactions in learner centred distance teaching beyond use of discussion forums and chats. Instead, the perspectives portrayed learner centredness in distance learning primarily as an individualised form of learning. This lack of emphasis on the social could be due to the difficulties related to promoting social interactions in contexts where individuals are learning asynchronously and coming from different communities and backgrounds. Yet, if the social is important to promoting learner centredness, there may need to be provision of the social in high school distance learning through attention to course design and teachers' strategies, for example through use of social networking software. 
According to teachers' perspectives, learner centredness in a distance learning, high school context means individualised, personalised learning designed according to the needs, goals, interests, and learning styles of learners. The statement that "interactions are one-on-one, because they're asynchronous" points to the role that asynchronous, online tools can play in supporting individualised pacing and flexibility. Communication by email supports one-on-one exchanges which, in themselves, can support more of an individualised focus on learners' needs, goals, and interests. The perspectives outline a role for teachers that involves on-demand, individualised facilitation. Course design is not driven by the instructor or by content but varies according to learners' needs, interests, styles, and pace. Learners work independently to achieve their goals.

Whereas knowledge of developmental differences such as disabilities might be important, such knowledge may not be easily available in a distance learning context. The fact that teachers' perspectives referenced the role of facilitators suggests that one of the few ways they can access information on those differences is through facilitators. In general, developmental differences may be more pronounced in distance learning because learners are geographically, organisationally and temporally dispersed and diverse.

Teachers' perspectives also emphasised the autonomous control, responsibility, and self regulation of distance learners. They emphasised the need for more proactive behaviours on the part of students, such as initiating contact with teachers, asking questions, asking other classmates for help, and using resources designed for learning autonomously and asynchronously. The autonomous nature of the learner and the need for self regulation in distance education is already well documented and discussed in the literature (see Moore, 1972, 1986, 1993; Moore \& Kearsley, 2005). However, autonomy in distance learning is not always discussed in relation to learner centredness. The ability of high school students to self regulate may not be welldeveloped, particularly if they are coming from a classroom environment where that ability was not required. Promoting learner centredness in a context of distance learning may therefore require that teachers help learners to manage their autonomy and to self regulate.

\section{Conclusions and implications}

The perspectives presented in this paper are limited to those of Canadian teachers and only to those at the high school level. Post-secondary teachers may or may not share the same perspectives on learner centredness. Future studies might explore learner centredness in other levels and contexts. A focus on teachers' individual as opposed to aggregated perspectives might have provided a more holistic and comprehensive insight into learner centredness. A case study approach to learner centredness could include a wider variety of variables than were considered in the study reported on in this paper. Variables such as school policies regarding distance learning, the amount of asynchronous versus synchronous contact with students, as well as type of course may potentially influence teachers' perspectives on learner centredness. It was beyond the scope of this study to include observations of teachers, so we do not know if their actual behaviours with regards to learner centeredness are congruent with their perspectives.

Our study did not consider the perspectives of students enrolled in distance learning. Do these students expect or desire student-to-student social interactions as part of their 
learning experience or do these interactions take place in parallel or outside of the learning context with other students, for example using social networking media such as Facebook or MySpace? If learner centredness in distance learning is, as the perspectives suggest, primarily achieved through individualised learning, is there a role for social interactions in distance learning as outlined in the LCPs? Are the two compatible? These are some of the questions that might be explored in future studies of distance learning and the LCPs framework.

The following table outlines potential implications for promoting learner centredness in distance learning at the high school level, based on our study's findings. The implications are grouped according to the four dimensions of the LCP framework.

Table 1: Summary of implications for promoting learner centeredness in distance learning at the high school level

\begin{tabular}{|c|c|}
\hline Cognitive and & Help students learn how to learn and control the learning process \\
\hline $\begin{array}{l}\text { metacognitive } \\
\text { factors }\end{array}$ & $\begin{array}{l}\text { Promote personal creativity and analysis as well as personalised } \\
\text { knowledge sharing and creation }\end{array}$ \\
\hline $\begin{array}{l}\text { Motivational and } \\
\text { affective factors }\end{array}$ & $\begin{array}{l}\text { Use relevance, choice, variety, and personal interest to play a } \\
\text { motivating role }\end{array}$ \\
\hline & $\begin{array}{l}\text { Allow student input in the course design to positively influence } \\
\text { student success }\end{array}$ \\
\hline & $\begin{array}{l}\text { Emphasise interactivity and relevance in course design, instead of } \\
\text { content }\end{array}$ \\
\hline Developmental & Students can lead collaborative online chats and discussions \\
\hline and social factors & $\begin{array}{l}\text { Teachers can focus on what is needed for individual students to do } \\
\text { well }\end{array}$ \\
\hline & Local facilitators can provide support \\
\hline $\begin{array}{l}\text { Individual } \\
\text { differences }\end{array}$ & $\begin{array}{l}\text { Accommodate students' differences so they can travel through } \\
\text { courses in unique ways }\end{array}$ \\
\hline factors & Let students' needs drive teachers' availability \\
\hline & Allow students' learning styles to drive learning \\
\hline & $\begin{array}{l}\text { Pay attention to and provide support for the learner's psychological } \\
\text { needs }\end{array}$ \\
\hline & Provide individualised assessment \\
\hline & Provide face to face visits where possible and necessary \\
\hline & $\begin{array}{l}\text { Rely on asynchronous learning to offer opportunities for flexibility } \\
\text { in pace and timelines and for one-on-one attention }\end{array}$ \\
\hline
\end{tabular}

\section{Acknowledgments}

The study reported on in this paper was funded by the Social Sciences and Humanities Research Council of Canada (SSHRC). Thank you to the teachers who participated in the study. Thank you to Charlie O'Keefe and Janine Murphy for help with recruitment and to Kate Scarth for transcribing the interviews and synthesising the data.

\section{References}

Alexander, P. A. \& Murphy, P. K. (1998). The research base for APA's Learner-Centered Psychological Principles. In N. M. Lambert \& B. L. McCombs (Eds.), How students learn: Reforming schools through learner-centered education (pp. 25-60). Washington, DC: American Psychological Association. 
APA Task Force on Psychology in Education (1993). Learner-centered psychological principles: Guidelines for school redesign and reform. Washington, DC: American Psychological Association and Mid-Continent Regional Educational Laboratory.

APA Work Group of the Board of Educational Affairs (1997). Learner-centered psychological principles: A framework for school reform and redesign. Washington, DC: American Psychological Association. [viewed 21 Jan 2008] http:/ / www.apa.org/ed/cpse/LCPP.pdf

Aviv, R. (2001). Educational performance of ALN via content analysis. Journal of Asynchronous Learning Networks, 4(2), 53-72. [verified 18 Oct 2009]

http: / / www.aln.org/publications/jaln/v4n2/pdf/v4n2_aviv.pdf

Bonk, C. J., Appelman, R. \& Hay, K. E. (1996). Electronic conferencing tools for student apprenticeship and perspective taking, Educational Technology, 36(5), 8-18.

Bonk, C. J. \& Cunningham, D. J. (1998). Searching for learner-centered, constructivist, and sociocultural components of collaborative educational learning tools. In C. J. Bonk \& K. S. King (Eds.), Electronic collaborators: Learner-centered technologies for literacy, apprenticeship, and discourse (pp. 25-50). Mahwah, NJ: Erlbaum.

Bonk, C. J. \& Reynolds, T. H. (1997). Learner-centred web instruction for higher-order thinking, teamwork, and apprenticeship. In B. H. Khan (Ed.), Web-based instruction (pp. 167-178). Englewood Cliffs, NJ: Educational Technology Publications.

Brush, T. \& Saye, J. (2000). Implementation and evaluation of a student-centered learning unit: A case study. Educational Technology Research and Development, 48(3), 79-100.

Carr-Chelman, A. \& Savoy, M. (2004). User-design research. In D. H. Jonassen (Ed.), Handbook of research on educational communications technology (2nd ed.) (pp. 701-716). New Jersey: Lawrence Erlbaum.

Crick, R. D. \& McCombs, B. L. (2006). The assessment of learner-centered practices surveys: An English case study. Educational Research and Evaluation, 12(5), 423-444.

Daniels, D., Kalkman, D. \& McCombs, B. L. (2001). Young children's perspectives of learning and teacher practices in different classroom contexts. Early Education and Development, 12(2), 253-273.

Hannafin, M. J. \& Land, S. M. (1997). The foundations and assumptions of technology-enhanced student-centered learning environment. Instructional Science, 25, 167-202.

Lambert, N. M. \& McCombs, B. L. (Eds.) (1998). How students learn: Reforming schools through learner-centered education. Washington, DC: American Psychological Association.

McCombs, B. L. (1997). Self-assessment and reflection: Tools for promoting teacher changes toward learner-centered practices. NASSP Bulletin, 81(1), 1-14.

McCombs, B. L. (1999). The assessment of learner-centered practices (ALCP): Tools for teacher reflection, learning, and change. Denver, CO: University of Denver Research Institute.

McCombs, B. L. (2000). Assessing the role of educational technology in the teaching and learning process: A learner-centered perspective. Paper presented at the meeting of the Secretary's Conference on Educational Technology: Measuring the Impacts and Shaping the Future, Washington, DC. (ERIC Document Reproduction Service No. ED452830). http:/ / www.eric.ed.gov:80/ERICWebPortal/ contentdelivery/servlet/ERICServlet?accno=ED452830 
McCombs, B. L. (2001a). Self-regulated learning and academic achievement: A phenomenological view. In B. J. Zimmerman \& D. H. Schunk (Eds.), Self-regulated learning and academic achievement: Theory, research, and practice (2nd ed.) (pp. 67-123). Mahwah, NJ: Erlbaum.

McCombs, B. L. (2001b). Young children's perspectives on learning and teacher practices in different classroom contexts: Implications for motivation. Early Education and Development, $12(2), 253-273$.

McCombs, B. L. (2003). A framework for the redesign of K-12 education in the context of current educational reform. Theory Into Practice, 42(2), 93-101.

McCombs, B. L. (2004). The learner-centered psychological principles: A framework for balancing a focus on academic achievement with a focus on social and emotional learning needs. In J. E. Zins, R. P. Weissberg, M. C. Wang, \& H. J. Walberg (Eds.), Building academic success on social and emotional learning: What does the research say? (pp. 23-39). New York: Teachers College Press.

McCombs, B.L. \& Lauer, P.A. (1997). Development and validation of the Learner-Centered Battery: Self assessment tools for teacher reflection and professional development. The Professional Educator, 20(1), 1-21.

McCombs, B. L. \& Miller, L. (2007). Learner-centered classroom practices and assessments: Maximizing student motivation, learning, and achievement. Thousand Oaks, CA: Corwin Press.

McCombs, B. L. \& Pierce, J. W. (1999). College level assessment of learner-centered practices (ALCP) student and teacher surveys. Denver, CO: University of Denver's Research Institute.

McCombs, B. L. \& Quiat, M. A. (2000a). A study of the learner-centeredness of the Community for Learning (CFL) Program, LSS Spotlight on Student Success, 500. [viewed 24 Sep 2009] http:/ / www.temple.edu/lss/pdf/spotlights/500/ spot500.pdf

McCombs, B. L. \& Quiat, M. A. (2000b). Results of pilot study to evaluate the Community for Learning (CFL) Program. [viewed 24 Sep 2009]

http: / / www.temple.edu/lss/pdf/ publications / pubs2000-1.pdf

McCombs, B. L. \& Vakili, D. (2005). A learner-centered framework for e-learning. Teachers College Record, 107(8), 1582-1600.

McCombs, B. L. \& Whisler, J. S. (1997). The learner-centered classroom and school. San Francisco, CA: Jossey-Bass.

Miles, M. \& Huberman, A. M. (1994). Qualitative data analysis: An expanded sourcebook. Thousand Oaks, CA: Sage.

Moore, M. G. (1972). Learner autonomy: The second dimension of independent learning. Convergence, 5(2), 76-88.

Moore, M. G. (1986). Self-directed learning and distance education. Journal of Distance Education, $1(1), 7-24$.

Moore, M. G. (1993). Theory of transactional distance. In D. Keegan (Ed.), Theoretical principles of distance education (pp. 22-38). London: Routledge.

Moore, M. G. \& Kearsley, G. (2005). Distance education: A systems view (2nd ed.). New York: Wadsworth. 
Murphy, E. \& Rodriguez-Manzanares, M. (2008a). Contradictions between the virtual and physical high-school classroom: A third generation activity theory perspective. British Journal of Educational Technology, 39(6), 1061-1072.

Murphy, E. \& Rodriguez-Manzanares, M. (2008b). High school teachers' beliefs about learnercentred e-learning, E-Learning, 5(4), 384-395.

Paris, C. \& Combs, B. (2000). Teachers' perspectives on what it means to be learner-centered. Paper presented at the Annual Meeting of the American Educational Research Association, New Orleans, LA. (ERIC Document Reproduction Service No. ED446070). http:/ / www.eric.ed.gov:80/ERICWebPortal/ contentdelivery/servlet/ERICServlet?accno=ED446070

Patton, M. Q. (2002). Qualitative research and evaluation methods (3rd ed.). Thousand Oaks, CA: Sage.

Reilly, D. H. (2005). Learner-centered education: Successful student learning in a nonlinear environment. Baltimore, MA: PublishAmerica.

Salisbury-Glennon, J. D., Gorrell, J., Sanders, S., Boyd, P. \& Kamen, M. (1999). Self-regulated learning strategies used by the learners in a learner-centered school. Paper presented at the Annual Meeting of the American Educational Research Association, Montreal. [verified 18 Oct 2009] http:/ / www.eric.ed.gov:80/ERICWebPortal/ contentdelivery/ servlet/ERICServlet?accno=ED434944

Seufert, S., Lechner, U. \& Stanoevska, K. (2002). A reference model for online learning communities. International Journal on E-Learning, 1(1), 43-54.

Somerindyke, J. L. (2001). How technology supports and constrains classroom life and learning: A case study of a fourth grade classroom. Unpublished doctoral dissertation, University of South Carolina.

Vakili, D. (2003). Online vs. face-to-face: A comparison of learner-centered practices and motivational variables in post-secondary classrooms. Unpublished doctoral dissertation, University of Idaho.

Wagner, E. D. \& McCombs, B. L. (1995). Learner centered psychological principles in practice: Designs for distance education. Educational Technology, 35(2), 32-35.

Ware, H. B. (2006). Learner-centered e-learning: An exploration of learner-centered practices in online and traditional instruction in higher education. Unpublished doctoral dissertation, Louisiana State University. http: / / etd.lsu.edu/ docs / available/ etd-11142006-115517/

Weimer, M. (2002). Learner-centered teaching: Five key changes to practice. San Francisco, CA: Jossey-Bass.

Weinberger, E. \& McCombs, B. L. (2001). The impact of learner-centered practices on the academic and non-academic outcomes of upper elementary and middle school students. Paper presented at the Annual Meeting of the American Educational Research Association, Seattle, WA. [verified 18 Oct 2009] http:// www.eric.ed.gov:80/ERICWebPortal/ contentdelivery/servlet/ERICServlet?accno=ED458276

Williams, P. A. (1996). Relationships between educational philosophies and attitudes toward learner-centered instruction. Paper presented at the Georgia Educational Research Association, Atlanta, GA. (ERIC No. ED406377). [viewed 15 Sep 2009] http:/ / www.eric.ed.gov:80/ERICWebPortal/ contentdelivery/servlet/ERICServlet?accno=ED406377 
Elizabeth Murphy, Faculty of Education, Memorial University of Newfoundland and Labrador, St. John's, NL A1B 3X8, Canada.

Email: emurphy@mun.ca. Website: http:/ / www.ucs.mun.ca/ emurphy /

Elizabeth Murphy holds a PhD in Educational Technology from Université Laval, Quebec. She is Associate Professor at the Faculty of Education, Memorial University of Newfoundland and Labrador, Canada. Her program of research focuses on teacher practices in e-learning and distance learning contexts.

Maria A. Rodriguez-Manzanares, Faculty of Education, Memorial University of Newfoundland and Labrador, St. John's, NL, A1B 3X8 Canada.

Email: mariar@mun.ca. Website: http:/ / mariarodriguez98.googlepages.com/

Maria A. Rodriguez-Manzanares is a doctoral candidate in the Faculty of Education at Memorial University of Newfoundland and Labrador, Canada, and a lecturer in the university's Department of French and Spanish and Faculty of Education. Her areas of interest include technology enhanced learning, international students, and second and foreign language learning. 